
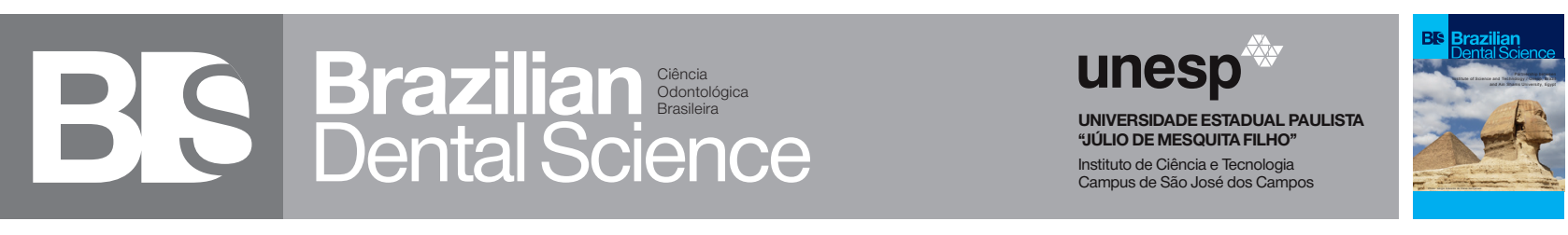

\title{
The effect of different surface treatments on color and translucency of bilayered translucent nano-crystalline zirconia before and after accelerated aging
}

O efeito de diferentes tratamentos de superfície na cor e translucidez da zircônia de dupla camada nano-cristalina translúcida antes e depois do envelhecimento

Mennatallah Mohie WAHBA ${ }^{1}$, Ashraf Hussien SHERIF ${ }^{1}$, Amr S. EL-ETREBY ${ }^{1,2}$, Tarek Salah MORSI ${ }^{2}$
1 - Fixed Prosthodontics Department - Faculty of Oral and Dental Medicine - Future University in Egypt - Cairo - Egypt.
2 - Fixed Prosthodontics Department - Faculty of Dentistry - Ain Shams University - Cairo - Egypt.

\section{ABSTRACT}

Objective: Despite the higher translucency of nanocrystalline Y-TZP than the conventional Y-TZP, it couldn't be used in the anterior region of the mouth in its fully anatomical form without veneering for better esthetics. This study evaluated the color change $(\Delta \mathrm{E})$ and translucency parameter (TP) of the bilayered nano-crystalline zirconia restorations after different treatments of the zirconia surface before and after accelerated aging. Material and Methods: Forty samples of inCoris TZI were cut in the form of discs $15 \mathrm{~mm}$ (diameter) and $1 \mathrm{~mm}$ (thickness) so that after sintering each disc dimensions' would be $12 \mathrm{~mm}$ (diameter) and $0.8 \mathrm{~mm}$ (thickness). All discs were colored by dipping in aqueous zirconia coloring solution of shade $\mathrm{A} 2$, then divided into four groups according to the type of surface treatment received before sintering; being tribochemical silica coating, zirconia powder deposition, glass grading, and a control untreated group. After sintering, all discs were veneered with a layer of porcelain 0.7 $\mathrm{mm}$ (thickness) and $12 \mathrm{~mm}$ (diameter). $(\Delta \mathrm{E})$ and TP were measured using VITA Easyshade Compact spectrophotometer before and after accelerated autoclave aging. Results: Different surface treatments applied had significant effect $(\mathrm{P}<0.05)$ over $\Delta \mathrm{E}$ and TP. Glass graded group showed the highest $\Delta \mathrm{E}$ value and the least TP value among both un-aged and aged sub-groups. Conclusion: Different surface treatments applied affected the color and translucency negatively where the control untreated group showed the highest TP and the least color deviation from the A2 color parameters. On the other hand, accelerated autoclave aging had no effect over translucency or color.

\section{KEYWORDS}

Aging; Ceramic restoration; Color; Translucent.

\section{RESUMO}

Objetivo: Apesar da maior translucidez da Y-TZP nanocristalina em relação à Y-TZP convencional, ela não pode ser usada na região anterior da boca em sua forma totalmente anatômica, sem o recobrimento cerâmico para uma melhor estética. Este estudo avaliou a mudança de cor $(\Delta \mathrm{E})$ e o parâmetro de translucidez (PT) das restaurações de zircônia nano-cristalina em duas camadas após diferentes tratamentos de superfície, antes e após o envelhecimento. Material e Métodos: Quarenta amostras de inCoris TZI foram cortadas na forma de discos de $15 \mathrm{~mm}$ (diâmetro) e $1 \mathrm{~mm}$ (espessura) para que, após sinterização, cada diâmetro dos discos fosse de $12 \mathrm{~mm}$ (diâmetro) e 0,8 mm (espessura). Todos os discos foram corados por imersão em solução aquosa de zircônia corante da sombra A2, divididos em quatro grupos de acordo com o tipo de tratamento de superfície recebido antes da sinterização; sendo revestimento de sílica químico-química, deposição de pó de zircônia, jateamento de vidro e um grupo de controle sem tratamento. Após a sinterização, todos os discos foram revestidos com uma camada de porcelana de $0,7 \mathrm{~mm}$ (espessura) e $12 \mathrm{~mm}$ (diâmetro). $\Delta \mathrm{E}$ e TP foram medidos usando o espectrofotômetro VITA Easyshade Compact antes e depois do envelhecimento em autoclave. Resultados: Diferentes tratamentos de superfície aplicados tiveram efeito significativo $(\mathrm{P}<0,05)$ sobre $\mathrm{AE}$ e maior $\mathrm{TP}$. valor $\mathrm{O}$ grupo com de $\Delta \mathrm{E}$ e o menor jateamento de vidro valor de TP apresentou entre os subgrupos não envelhecidos e envelhecidos. Conclusão: Diferentes tratamentos de superfície aplicados afetaram negativamente a cor e a translucidez, onde o grupo controle sem tratamento apresentou o maior TP e o menor desvio de cor dos parâmetros de coloração A2. Por outro lado, o envelhecimento acelerado da autoclave não teve efeito sobre a translucidez ou a cor.

\section{PALAVRAS-CHAVE}

Envelhecimento; Restauração cerâmica; Cor; Translúcido. 


\section{INTRODUCTION}

$\mathrm{D}$ uring the last few decades, the demand for metal-free restorations, being conditioned by both social pressures and interests of dental profession has increased dramatically and a climate of non-acceptance of metal alloys in the oral cavity prevailed [1]. Recently and over the previous few years, zirconia has propelled a rapid development of metal-free dentistry where it represents a versatile material owing to its excellent mechanical properties, biocompatibility and relatively enhanced esthetic properties.

Since the esthetic value of a ceramic restoration is based on its ability to harmonize with the natural tooth, key optical factors that permit a pleasing harmony such as color, and translucency must be adressed [2,3].

Color difference $(\Delta \mathrm{E})$ is used to describe whether the changes in the overall shade are perceivable to the human observer. For many authors, average color differences below 3.7 have been rated as a match in the oral environment [4-7]. On the other hand, Paravina $\mathrm{R}$ et al [8] reported a $(\Delta \mathrm{Eab})=2.7$ as being an accepted match.

In addition to color match, translucency has been always identified as a paramount factor for the success of ceramic restorations $[2,3]$. One method for measuring a material's translucency is through translucency parameter (TP) which is defined as the color difference of a material of a given thickness over white and black backgrounds, and corresponds directly to common visual assessments.

Advances in industrial facilities and the improvements in nano-technology, led to the evolution of nano-structured polycrystalline zirconia in an attempt to improve esthetic value of zirconia core materials [9]. Yet, and despite the fact that nano-crystalline full-contour zirconia is reported to have high transcluceny, for better esthetic results, it's advised to use individually veneered structures [10].

Owing to the inertness and surface stability of Y-TZP, establishing a durable chemical or mechanical bond between zirconia and veneering porcelain was proven to be a difficult task [11]. Accordingly, and to ensure structural integrity of such layered restorations different surface treatment methods of the zirconia substructure have been investigated. Among these methods are fusion sputtering that was introduced by Aboushelib M in 2012 [12], tribochemical silica-coating or silicatization using CoJet ${ }^{\mathrm{TM}}$ at the dentist's surgery as well as the functionally graded glass/zirconia/glass structure (GGZ) based on the idea of grading a brittle material with a material of lower modulus of elasticity at the external surface $[13,14]$. However, such treatments might affect the quality of the surface in terms of topography and optical properties. This would in return affect the behavior of the incident light from underneath the inherently translucent veneering porcelain and consequently have an effect on the color and translucency of the whole bilayered structure.

Another major drawback we face when using Y-TZP is low temperature degradation (LTD) which is the spontaneous tertragonal to monoclinic (t-m) transformation occurring over time at low temperature and humid atmosphere. This phenomenon has multiple consequences that include surface degradation, grain pullout, micro-cracking and strength and esthetic degradation $[15,16]$. The effect of LTD on multiple types of monolithic zirconia was investigated and it was reported that there was a high chance for monolithic Y-TZP to undergo low temperature degradation, a thing that might significantly affect the translucency [17]. Since autoclave treatment was proven to induce some degree of aging with notable increase in the m-phase content, it was a good method to propose an accelerated test for LTD to facilitate the simulation of LTD in the laboratory [18].

Owing to the presumably important effect of LTD on zirconia esthetics and reverting to the fact that nanocrystalline Y-TZP shouldn't be used in its full anatomical form without veneeringin the anterior region of the mouth- for better 
esthetic results, a question was raised about the effect of the different surface treatments used for bonding between zirconia and the veneering porcelain on the optical properties of zirconia. Consequently, that In-vitro study was carried out to evaluate color change and translucency parameter of the translucent nano-crystalline bilayered zirconia restorations after different treatments of the zirconia surface before and after accelerated autoclave aging.

The null hypothesis was that neither the different surface treatments of nano-crystalline zirconia surface nor the low temperature degradation would have an effect on both color and translucency parameter.

\section{MATERIAL AND METHODS}

Forty samples of inCoris TZI (Sirona Dental Systems, Bensheim, Germany) were cut in the form of zirconia discs $15 \mathrm{~mm}$ (diameter) $\mathrm{x} 1 \mathrm{~mm}$ (thickness) so that final dimensions after sintering would be $12 \mathrm{~mm}$ (diameter) x $0.8 \mathrm{~mm}$ (thickness). Each zirconia sample was finished wet using waterproof silicon carbide sandpaper (Matador SoftFlex, Germany) of different grit size ranging from 320 to 1200 .

All zirconia discs were colored by dipping in aqueous zirconia coloring solution and then received different surface treatments before being sintered.Samples were divided into four groups $(n=10)$ according to the type of surface treatment received; being tribochemical silica coating, zirconia powder deposition, or glass grading, and a control untreated group.

For the tribochemically coated samples, pre-sintered zirconia discs were silica coated with $30 \mu \mathrm{m}$ silicatized sand particles (Cojet) (3M ESPE, USA) at pressure of 3 bars for 10 seconds using air prophy unit (Sunny,China) mounted on the dental unit. Specially designed mold (15 mm diameter x 1 $\mathrm{mm}$ height for pre-sintered discs) was constructed to fix the samples at a distance of $1 \mathrm{~cm}$ from the air prophy unit and prevent their movement during the silica coatings. For samples that received zirconia powder coating, each pre-sintered zirconia sample was coated with $30 \mathrm{~nm}$ Y-TZP powder (Inramat, Advanced Materials, Manchester CT) at pressure of 3 bars for 5 seconds and at a distance of $2 \mathrm{~cm}$ from the nozzle of the air prophy unit mounted on the dental unit and fixed with the same especially designed mold. In the glass graded group, each presintered zirconia sample was coated with a single layer $(0.1 \mathrm{~mm})$ of powdered glass slurry (Akzent Glaze) (Vita, Zahnfabrik H. Rauter GmbH\&Co. $\mathrm{KG}$ ) and firing of the porcelain glass layer took place during the same cycle of zirconia sintering. Thickness of the glass slurry was controlled and adjusted using a specifically designed mold (Figure 1). After sintering, each sample in the glass graded group was finished with water proof silicon carbide sandpaper of grit size 1200 and then the glassgraded and ground surface of each sample was etched with hydroflouric acid 8\% (Dentobond Porcelain Etch) (Itena Clinical, Paris, France) for one minute then washed under running water and air dried.

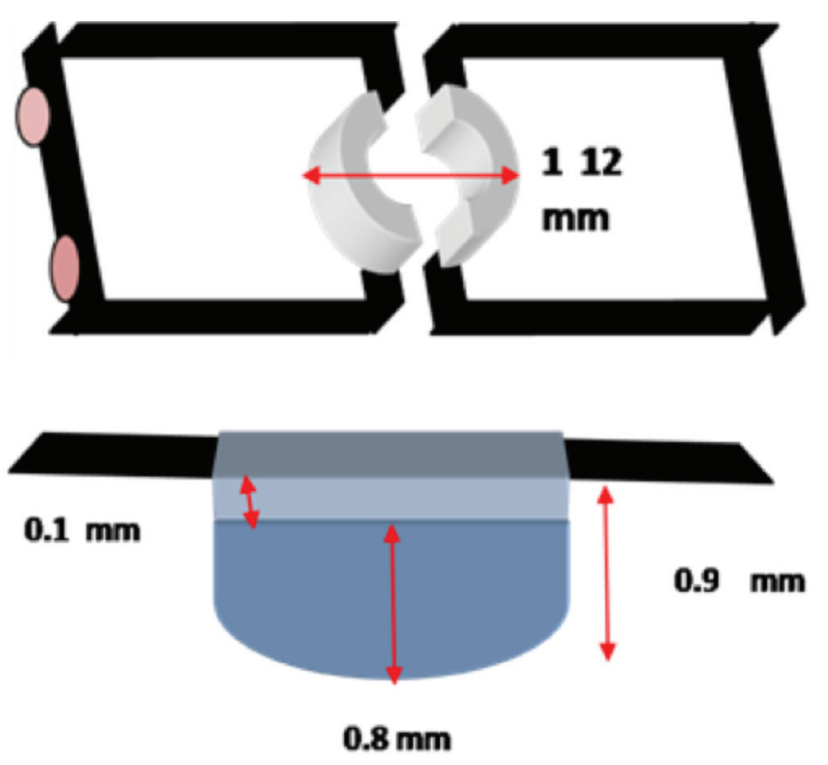

Figure 1- Diagrammatic drawing showing a specially designed mold for glass layer thickness adjustment.

All samples were then veneered with $0.7 \mathrm{~mm}$ thick layer of veneering porcelain VM9 Enamel Light (ENL) (Vita, Zahnfabrik H. Rauter GmbH\&Co. KG) powder and liquid and of the same diameter as the zirconia discs (12 mm) using a two-part teflon mold to control the thickness of the veneering porcelain. 
After veneering, all veneered translucent nanocrystalline zirconia discs were finished and polished using a fine polishing disc of porcelain polishing kit (Microdont, São Paulo, Brazil) in a straight handpiece and then glazed with VITA AKZENT glaze and fired.

Both color change and translucency parameter were measured using VITA Easyshade Compact (Vita, Zahnfabrik H. Rauter GmbH\&Co. KG) spectrophotometer that has been previously used in multiple studies for the same purpose. This is reverted to its reliability since it is powered by internal light source based on D-65 illuminant thus the environmental lightening conditions don't influence its color measurements. Relying on large diameter fiber optics arranged in a stainless steel probe that can illuminate the surface and receive light that is internally scattered, it avoids the specular reflected light that contains little or no color information and that can negatively affect the color measurement [19-22]. During measurements the $5 \mathrm{~mm}$ diameter contact probe tip was placed at the center of each specimen from the veneered side.

For Color change measurement VITA Easyshade Compact was set to the "Restoration mode" and shade A2 was selected. Color difference $(\Delta \mathrm{E})$ between the specimen and the selected shade was calculated inside the device according the equation $\Delta \mathrm{E}=\left[\left(\Delta \mathrm{L}^{*}\right) 2+\left(\Delta \mathrm{a}^{*}\right) 2+\left(\Delta \mathrm{b}^{*}\right)^{2}\right]^{1 / 2}$ where $\mathrm{L}^{*}$ coordinate represents the lightness-darkness of the specimen. The $\mathrm{a}^{*}$ coordinate expresses the chroma along the red-green axis. The $b^{*}$ coordinate measures chroma along the yellow-blue axis. $\Delta \mathrm{L}^{*}$, $\Delta \mathrm{a}^{*}$ and $\Delta \mathrm{b} *$ are the differences in the CIE color space parameters between the pre-set values of the shade A2 in the VITA Easyshade Compact and those of the measured specimens.

In all color measurments, specimens were placed against a standard white background (CIE $\mathrm{L}^{*}=82.4, \mathrm{a}^{*}=20.1$, and $\mathrm{b}^{*}=20.6$ ) to minimize the influence of background on color.

For translucency measurement, each sample was measured against both black and white backgrounds using tooth single mode of EasyShade where in each time, CIE Lab values were calculated. The translucency parameter (TP) was obtained by calculating the color difference of the specimen over the black and white backgrounds with the following equation;

$$
\mathrm{TP}=\left[\left(\mathrm{L}^{*}{ }_{\mathrm{B}}-\mathrm{L}^{*}{ }_{\mathrm{W}}\right)^{2}+\left(\mathrm{a}_{\mathrm{B}}{ }_{\mathrm{B}}-\mathrm{a}^{*}{ }_{\mathrm{w}}\right)^{2}+\left(\mathrm{b}^{*}{ }_{\mathrm{B}}-\mathrm{b}^{*}{ }_{\mathrm{W}}\right)^{2}\right]^{1 / 2}[23] \text {. }
$$

Where subscript " $\mathrm{B}$ " refers to the color coordinates over a black background and the subscript "W" refers to those over a white background.

Same procedures of color and translucency measurement were carried out again after samples of each group were subjected to accelerated aging in a steam autoclave (Sturdy SA-260MA- Class B) (Sturdy Industrial Co.LTD, New Taipei City, Taiwan) at $134^{\circ} \mathrm{C}$ with 2 bars pressure for 4 consecutive cycles (each cycle being 45 minutes) which was clinically representative of approximately 9 years of intraoral service [24].

All data was collected, tabulated and subjected to statistical analysis. Statistical analysis was performed by SPSS in general (version 17), also Microsoft office Excel was used for data handling and graphical presentation. Independent samples t-test was used for comparing the means of the same variable between aged and un-aged groups. One way analysis of variance (ANOVA) was used for comparing the means of different groups both for aged and un-aged conditions. Dunnett's test was used for comparing each group with the control. Multiple comparison Bonferroni method was used for comparing each two groups together. Significance level was considered at $(P<0.05)$. Two-tailed tests were assumed through- out the analysis for all statistical tests.

\section{RESULTS}

Results showed that different surface treatment methods applied had significant effect $(\mathrm{P}<0.05)$ over color change and translucency parameter. When color change $(\Delta \mathrm{E})$ and translucency parameter were calculated, the glass graded group showed the highest amount of color change and the least (TP) value among both un-aged and aged sub-groups (Table 1). 
Table 1- Multiple comparison tests sowing the effect of different surface treatments and independent samples t-test comparing the mean TP, $\Delta E, C I E L^{*}, a^{*}, b^{*}$ values between un-aged and aged sub-groups in different surface treatment groups

\begin{tabular}{|c|c|c|c|c|c|c|c|c|c|c|}
\hline & \multicolumn{2}{|c|}{ TP } & \multicolumn{2}{|c|}{$\Delta \mathbf{E}$} & \multicolumn{2}{|c|}{$L^{*}$ Value } & \multicolumn{2}{|c|}{$a^{\star}$ Value } & \multicolumn{2}{|c|}{$b^{\star}$ Value } \\
\hline & Unaged & Aged & Unaged & Aged & Unaged & Aged & Unaged & Aged & Unaged & Aged \\
\hline & $\begin{array}{l}\text { Mean } \\
\text { (S. D.) }\end{array}$ & $\begin{array}{l}\text { Mean } \\
\text { (S. D) }\end{array}$ & $\begin{array}{l}\text { Mean } \\
\text { (S. D.) }\end{array}$ & $\begin{array}{l}\text { Mean } \\
\text { (S. D.) }\end{array}$ & $\begin{array}{l}\text { Mean } \\
\text { (S. D) }\end{array}$ & $\begin{array}{l}\text { Mean } \\
\text { (S. D.) }\end{array}$ & $\begin{array}{l}\text { Mean } \\
\text { (S. D.) }\end{array}$ & $\begin{array}{l}\text { Mean } \\
\text { (S. D) }\end{array}$ & $\begin{array}{l}\text { Mean } \\
\text { (S. D.) }\end{array}$ & $\begin{array}{l}\text { Mean } \\
\text { (S. D.) }\end{array}$ \\
\hline Control & $\begin{array}{c}9.15^{\mathrm{a}} \\
(0.36)\end{array}$ & $\begin{array}{l}9.73^{\mathrm{a}} \\
(0.91)\end{array}$ & $\begin{array}{l}11.5996^{c} \\
(0.8137)\end{array}$ & $\begin{array}{l}12.2466^{c} \\
(0.6525)\end{array}$ & $\begin{array}{l}0.006^{b} \\
(0.118)\end{array}$ & $\begin{array}{l}0.393^{a} \\
(0.150)\end{array}$ & $\begin{array}{l}13.099^{\mathrm{a}} \\
(0.595)\end{array}$ & $\begin{array}{c}13.306^{a^{*}} \\
(0.480)\end{array}$ & $\begin{array}{c}93.366^{c} \\
(1.303)\end{array}$ & $\begin{array}{c}93.606^{c} \\
(1.732)\end{array}$ \\
\hline Cojet & $\begin{array}{l}9.76^{a} \\
(0.71)\end{array}$ & $\begin{array}{l}9.41^{\mathrm{a}} \\
(0.44)\end{array}$ & $\begin{array}{c}14.9798^{b} \\
(0.5847)\end{array}$ & $\begin{array}{l}14.2530^{\mathrm{b}} \\
(0.6093)\end{array}$ & $\begin{array}{l}0.506^{a} \\
(0.192)\end{array}$ & $\begin{array}{l}0.433^{a} \\
(0.184)\end{array}$ & $\begin{array}{l}10.353^{b} \\
(1.333)\end{array}$ & $\begin{array}{l}9.919^{b} \\
(1.382)\end{array}$ & $\begin{array}{c}95.459^{\mathrm{b}} \\
(1.30)\end{array}$ & $\begin{array}{l}96.079^{\mathrm{b}} \\
(0.947)\end{array}$ \\
\hline $\begin{array}{l}\text { Zirconia } \\
\text { Powder }\end{array}$ & $\begin{array}{l}7.98^{b} \\
(0.33)\end{array}$ & $\begin{array}{l}7.92^{b} \\
(0.75)\end{array}$ & $\begin{array}{l}14.2462^{b} \\
(0.5003)\end{array}$ & $\begin{array}{c}13.8664^{b} \\
(0.6371)\end{array}$ & $\begin{array}{c}-0.006^{b} \\
(0.121)\end{array}$ & $\begin{array}{l}0.259^{a} \\
(0.155)\end{array}$ & $\begin{array}{l}9.799^{\mathrm{b}} \\
(0.369)\end{array}$ & $\begin{array}{l}9.393^{b^{*}} \\
(0.535)\end{array}$ & $\begin{array}{c}94.312^{\mathrm{bc}} \\
(0.725)\end{array}$ & $\begin{array}{c}94.433^{\text {bc }} \\
(0.716)\end{array}$ \\
\hline $\begin{array}{l}\text { Glass } \\
\text { Graded }\end{array}$ & $\begin{array}{l}0.65^{c} \\
(0.47)\end{array}$ & $\begin{array}{l}0.76^{c} \\
(0.40)\end{array}$ & $\begin{array}{l}20.7462^{\mathrm{a}} \\
(0.2254)\end{array}$ & $\begin{array}{c}21.6530^{a^{*}} \\
(0.3785)\end{array}$ & $\begin{array}{l}-0.613^{c} \\
(0.107)\end{array}$ & $\begin{array}{c}-0.486^{b} \\
(0.112)\end{array}$ & $\begin{array}{l}2.639^{c} \\
(0.228)\end{array}$ & $\begin{array}{l}3.039^{c} \\
(0.279)\end{array}$ & $\begin{array}{c}98.706^{a} \\
(0.776)\end{array}$ & $\begin{array}{c}98.513^{\mathrm{a}^{*}} \\
(1.281)\end{array}$ \\
\hline
\end{tabular}

Different superscripts $(a, b, c)$ indicate presence of significance between different surface treatment groups in same column. (*) Indicates presence of significance between unaged and aged subgroups.

S.D. stands for standard deviation.

\section{COLOR MEASUREMENTS}

\section{$L^{*}$ Value Measurements}

Multiple comparison tests showed that there was significant difference of the $L^{*}$ value between the un-aged sub-groups of all groups as well as between the aged sub-groups of all groups except between the control and zirconia powder deposition groups and between the cojet and zirconia powder deposition groups. While for the effect of aging, paired samples t-test showed that there was no significant difference in $L^{*}$ value before and after aging in all surface treatment groups. It was shown also that the control group displayed the lowest $\mathrm{L}^{*}$ value while the glass graded group displayed the highest $L^{*}$ value (Figure 2 ).

\section{a* Value Measurements}

Multiple comparison tests showed that there was a significant difference for the a* value between all un-aged subgroups in all surface treatment groups except between the control and zirconia powder deposition groups. As for the aged sub-groups, there was significant difference in the $\mathrm{a}^{*}$ value between control and glass graded groups, cojet and glass graded groups as well as between zirconia powder deposition and glass graded groups. Paired sample t-test showed that there was significant difference in the $a^{*}$ value before and after aging in both the control group and the zirconia powder deposition groups where in both groups aging caused a significant shift towards the red zone of color. On the other hand, aging had no significant effect on the $a^{*}$ value in both the cojet and glass graded groups (Figure 3 ).

\section{b* Value Measurements}

Multiple comparison tests showed that there was significant difference in $b^{*}$ value between both the un-aged sub-groups in all groups as well as between the aged sub-groups in all groups except between the cojet and zirconia powder deposition groups.

Paired sample t-test showed that there was no significant difference in the $b^{*}$ value before and after aging for all groups except in the glass graded group where aging caused a significant shift in the yellow zone of color (Figure 4).

\section{$\Delta \mathrm{E}$ Measurements}

Multiple comparison tests showed that there was significant difference in the $\Delta \mathrm{E}$ value 
between un-aged sub-groups of all groups as well as between the aged sub-groups of all groups except between cojet and zirconia powder deposition groups. Paired sample t-test showed that aging had no significant effect over $\Delta \mathrm{E}$ values except in the glass graded group. For all groups-either before or after aging- $\Delta \mathrm{E}$ values were far above both the perceptible and acceptable range (Figure 5).

\section{Translucency Parameter Measurements}

Multiple comparison tests showed that there was significant difference in the TP value of un-aged sub-groups for all surface treatment groups as well as among the aged sub-groups for all groups except between the control and cojet groups. Paired sample t-test showed that aging caused no significant difference in the (TP) value for all surface treatment groups before and after aging. (TP) value was highest for the control group and lowest for the glass graded group (Figure 6).

\section{Mean L* Value}

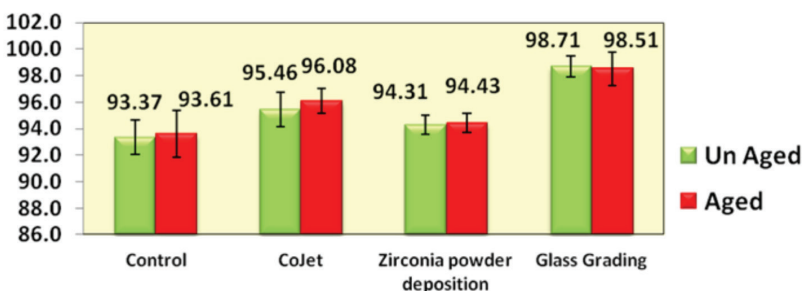

Figure 2 - Bar chart showing mean of $L^{*}$ value in relation to different surface treatments before and after aging.

Mean a* Value

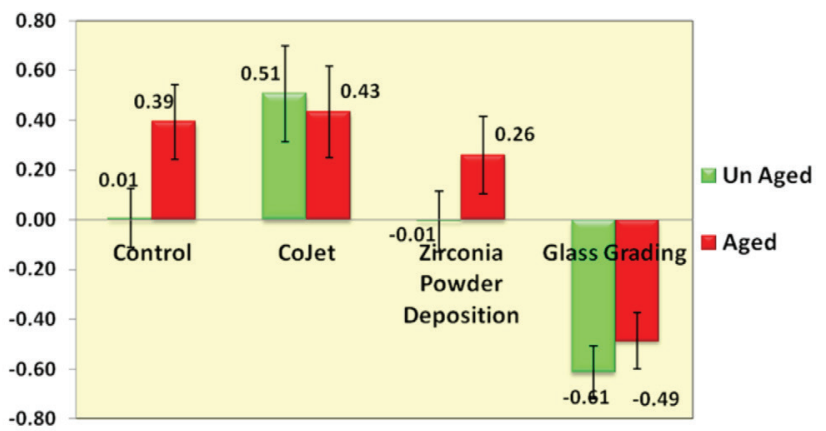

Figure $\mathbf{3}$ - Bar chart showing means of $\mathrm{a}^{*}$ value in relation to different surface treatments before and after aging.

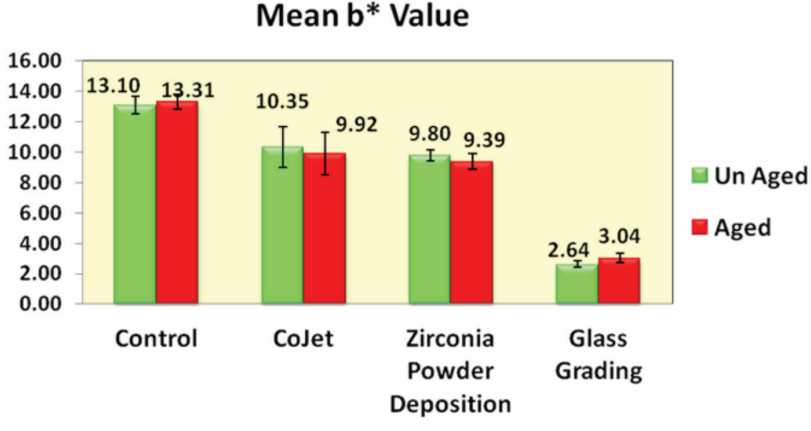

Figure 4 - Bar chart showing means of $b^{*}$ value in relation to different surface treatments before and after aging.

\section{Mean $\Delta \mathrm{E}$ Value}

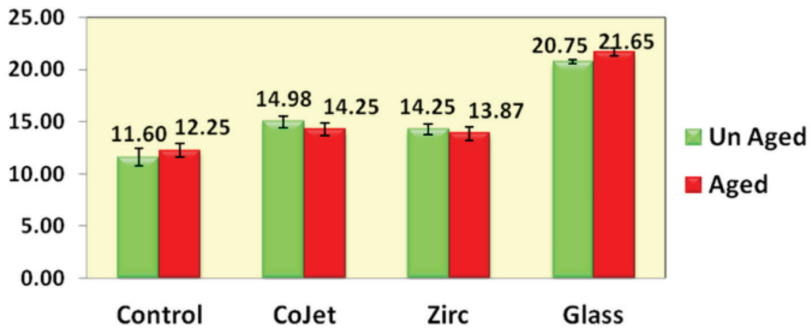

Figure 5 - Bar chart showing means of $\Delta \mathrm{E}$ in relation to different surface treatments before and after aging.

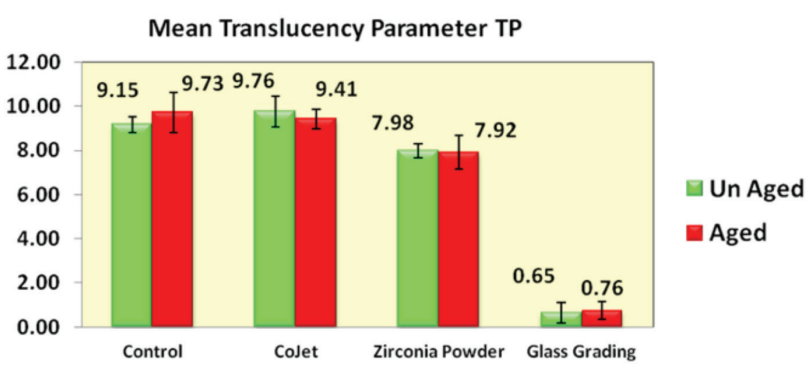

Figure 6 - Bar chart showing means of (TP) in relation to different surface treatments before and after aging.

\section{DISCUSSION}

An up-to-date complaint of full-contour zirconia is its relative opacity and lack of translucent ivory color of natural teeth [25]. For this reason, and for the sake of producing an esthetically optimized restoration with pronounced anatomical structure design, it's advised to use individually veneered structures made of translucent zirconia restorations in cases of high esthetic standards [10]. 
With zirconia being a polycrystalline material with no glass phase, bonding with the veneering porcelain becomes difficult. Different surface treatment methods of the zirconia surface have been tried in an attempt to achieve an optimum bonding at the zirconia-veneer interface. With esthetics of a restoration being a paramount concern, the effect of different surface treatments on the CIELab values, color change and translucency parameter of the zirconiaveneered discs was investigated. Bearing in mind that low-temperature degradation (LTD) has been associated with several Y-TZP-based biomaterials $[16,26]$, samples were tested before and after aging.

Since it has been well-established in literature that the evaluation of all-ceramic restorations over five years of service is considered the gold standard and since a period of ten years is considered a reasonable lifetime for dental restoration to function in the oral cavity, samples-in the current study- were subjected to autoclave aging for 3 hours at $134^{\circ} \mathrm{C}$ and 2 bar.

According to the obtained results, it was shown that the null hypothesis of the study was partially accepted.

For $L^{*}$ value representing the degree of lightness and darkness, it was noted that in the unaged sub-groups, glass graded samples showed the highest values while the control group specimens had the lowest values. This could be attributed to the whitish color of the low fusing porcelain used for glass grading. Color changes of ceramic materials may also occur from metal oxides that are added to ceramic materials in order to obtain acquired color shades [27].

There was significant difference between all groups, in both the un-aged and aged subgroups, except between control group and zirconia powder deposition and between cojet and zirconia powder deposition with the high values for the cojet group being probably due to the color of the cojet powder.
No significant difference was noted between the control and the zirconia powder deposition groups since both surfaces are composed of nano-crystalline yttria-stabilized zirconia.

Regarding the a* value representing the red-green axis scale of color, all unaged subgroups, except glass grading group, the a* value was in the red zone of color with the cojet group showing a shift in the red zone away from the base-line. This was probably due to the effect of cojet powder color. In case of glass graded group, there was notable shift in color towards the green zone which might be attributed to the coloring pigments present in the low fusing porcelain [27].

Control and zirconia deposition groups showed no significant difference regarding the $a^{*}$ value because both surfaces are composed of nano-crystalline zirconia.

After aging, no significant difference in $a^{*}$ value was reported between the cojet and control groups and between the cojet and zirconia groups because aging caused surface uplifting, micro-cracks and enhanced water penetration causing shift in the $\mathrm{a}^{*}$ value in both the control and zirconia deposition groups while the cojet group wasn't affected by aging due to the effect of silica that could have in suppressing water penetration and degradation $[28,29]$.

No significant difference was seen before and after aging in each group except in the zirconia and the control groups where aging had a significant effect causing notable shift in the reddish zone. This could be due to the phase transformation at the surface of the specimens which would change its optical reflection [30].

For the $b$ *value representing the yellowblue axis of color, all groups appeared to fall in the yellow zone of color with the glass graded group showing the lowest $b^{*}$ value which is probably due to the coloring pigments present in the low fusing porcelain. 
There was no significant difference in each group before and after aging except in the glass graded group where aging had caused a higher shift towards the yellowish zone. This shift might be attributed to the break-down of the coloring pigments, present in the low fusing porcelain, when subjected to repeated heat exposure through autoclave aging [31,32].

Having a look on the $\Delta \mathrm{E}$ values, showing the color change, with different surface treatment methods before and after aging, it was noted that all values ranged between 11.6 and 21.6. These values were far beyond both the perceptible and acceptable values based on a clinical study which reported that the perceivable color difference for $50 \%$ of the dentists was $\Delta$ Eab 2.6 while that at which $50 \%$ of the dentists would go for remake of the restoration due to color mismatch was 5.5 units [33]. Such high values for $\Delta \mathrm{E}$, even for the untreated group, might be attributed to the time used for coloring of the zirconia discs or the dipping method where coloring oxides might be damaged when subjected to high sintering temperatures $[34,35]$. Another factor that might have caused those high $\Delta \mathrm{E}$ values is the veneering porcelain since Luo $X$. and Zhang LS [36] showed that $b$ * value increased significantly after veneering causing specimens to be more colorful.

In our study, it was seen that there was significant difference in all groups-in both unaged and aged sub-groups- except between cojet and zirconia deposition groups.No significant difference was reported in each group of surface treatment before and after aging except in the glass graded group in which aging caused a higher change in color. This color change was probably due to the effect of aging causing a shift towards the yellowish zone subsequent to the breakdown of the coloring pigments of the low fusing porcelain [31,32].

For translucency measurements, authors of the study chose using translucency parameter (TP) instead of contrast ratio (CR) measurement as it corresponds directly to the common visual assessment of translucency [37]. Besides Spink et al. [38] concluded that CR, which measures diffuse reflectance, does not detect small changes in light transmission, when materials present high scattering and absorption coefficients.

TP representing the translucency of samples was shown to be highest for the control group receiving no surface treatment at all and lowest for the glass graded group with all groups showing significantly different values in both sub-groups except between the control and cojet.

On the other hand, glass graded group showed significantly lower translucency values due to the high opacity of the low fusing porcelain used for glass grading [27].

For the present study, significantly lower TP value for the zirconia deposition group may be attributed to the formation of clusters of zirconia powder during blasting. Such clusters, having indefinite arrangement, might cause scattering of light and decrease of translucency, where it has been proved in previous work that light scattering is a primary reason for the opacity of most ceramics $[39,40]$. These clusters might also decrease the wettability of the veneering porcelain on the zirconia surface causing voids formation that act as site for light entrapment, preventing passage of light and decreasing the material's translucency [41]. The formation of such clusters of zirconia powder is similar to findings of previous studies where Aboushelib M. [12] reported the presence of $8-12 \mu \mathrm{m}$ retentive beads made of zirconia dioxide material on the surface when viewed under the SEM. Also, Teng J et al. [42] stated the presence of rugged surface with abundant micro-porosities when coated zirconia specimens were examined under the scanning electron microscope.

Inside each surface treatment group, there was no significant difference in the TP value before and after aging showing that aging had no effect on the samples' translucency. Such results appear to agree with what was previously stated by Abdelbary O et al. [43] who showed that aging had no significant effect on TP of nano-crystalline Y-TZP when used in thick sections (0.8-1.2 mm). 
Accordingly and within the limitations of that study, it's best recommended that in cases of high esthetic standards where individually veneered structures might be needed to apply the veneering porcelain layer over the zirconia surface directly with no special surface treatments. Yet, further research is needed to determine whether the application of veneering porcelain directly on the zirconia surface with no special treatment is enough for achievement of good bond at the interface or further treatments should be tried.

\section{CONCLUSIONS}

The different types of surface treatments applied in the previous study affected the color and translucency negatively where the control untreated group showed the highest translucency parameter and the least color deviation from the A2 color parameters set on the Easyshade spectrophotometer.On the othe hand, accelerated autoclave aging had no effect over either color or translucency.

\section{REFERENCES}

1. Agustín-Panadero R, Román-Rodríguez JL, Ferreiroa A, Solá-Ruíz MF, Fons-Font A. Zirconia in fixed prosthesis. J Clin Exp Dent. 2014 Feb 1;6(1):e66-73. doi: 10.4317/jced.51304. eCollection 2014 Feb.

2. Michalakis K. Light transmission of post and cores used for the anterior esthetic region. Int J Periodontics Restorative Dent. 2004 0ct;24(5):462-9.

3. Lee YK, Cha HS, Ahn JS. Layered color of all- ceramic core and veneer ceramics. J Prosthet Dent. 2007 May;97(5):279-86.

4. Ruyter IE, Nilner K, Moller B. Color stability of dental composite resin materials for crown and bridge veneers. Dent Mater. 1987 Oct;3(5):246-51.

5. Seghi RR, Hewlett ER, Kim J. Visual and instrumental colorimetric assessments of small color differences on translucent dental porcelain. J Dent Res. 1989 Dec;68(12):1760-4

6. Johnston WM, Kao EC. Assessment of appearance match by visual observation and clinical colorimetry. J Dent Res. 1989 May;68(5):819-22.

7. Douglas RD, Brewer JD.Acceptability of shade differences in metal ceramic crowns. J Prosthet Dent. 1998 Mar;79(3):254-60.

8. Paravina RD, Ghinea R, Herrera LJ, Bona AD, Igiel C, Linninger M, et al. Color difference thresholds in dentistry. J Esthet Restor Dent. 2015 Mar-Apr;27 Suppl 1:S1-9. doi: 10.1111/jerd.12149. Epub 2015 Apr 17.
9. Heffernan MJ, Aquilino SA, Diaz-Arnold AM, Haselton DR, Stanford CM, Vargas MA. Relative translucency of six all-ceramic systems. Part I: core materials. J Prosthet Dent. 2002 Jul;88(1):4-9.

10. Rinke S, Fischer C. Range of indications for translucent zirconia modifications: Clinical and technical aspects. Quintessence Int. 2013;44(8):557-66. doi: 10.3290/j.qi.a29937.

11. Guazzato M, Proos K, Sara G, Swain MV. Strength, reliability and mode of fracture of bilayered porcelain/core ceramics. Int J Prosthodont. 2004 Mar-Apr;17(2):142-9.

12. Aboushelib M. Fusion sputtering for bonding to zirconia based materials. J Adhes Dent. 2012 Aug;14(4):323-8. doi: 10.3290/j.jad. a25684.

13. Zhang Y, Kim JW. Graded structures for damage resistant and aeshtetic all-ceramic restorations. Dent Mater. 2009 Jun;25(6):781-90. doi: 10.1016/j.dental.2009.01.002. Epub 2009 Feb 1.

14. Ren L, Janal MN, Zhang Y. Sliding contact fatigueof graded zirconia with external esthetic glass. J Dent Res. 2011 Sep;90(9):1116-21. doi: 10.1177/0022034511412075. Epub 2011 Jun 10.

15. Ali S, Karthigeyan S, Deevanai M, Mani R. Zirconia:Properties and applications. A review. Pak Oral Dental J. 2014;34(1):178-83.

16. Denry I, Kelly R. State of the art of zirconia for dental applications. Dent Mater. 2008 Mar;24(3):299-307. Epub 2007 Jul 19.

17. Fathy SM, El-Fallal AA, El-Negoly-SA, Abu Baker El Bedawy A. Translucency of monolithic and core zirconia after hydrothermal aging. Acta Biomater Odontol Scand. 2015 Dec 23;1(2-4):86-92. Epub 2015 Nov 9.

18. Lee TH, Lee SH, Her SB, Chang WG, Lim BS. Effects of surface treatments on the susceptibilities of low temperature degradation by autoclaving in zirconia. J Biomed Mater Res B Appl Biomater. 2012 Jul;100(5):1334-43. doi: 10.1002/jbm.b.32700. Epub 2012 May 7.

19. Kurtulmus-Yilmaz S, Ulusoy M. Comparison of the translucency of shaded zirconia all-ceramic systems. J Adv Prosthodont. 2014 Oct;6(5):415-22. doi: 10.4047/jap.2014.6.5.415. Epub 2014 Oct 21.

20. Perroni P, Bergoli D, Dos Santos F, Moraes R, Boscato N. Spectrophotometric analysis of clinical factors related to the color of ceramic restorations: A pilot study. J Prosthet Dent. 2017;118(5):611-16

21. Wahba MM, El-Etreby SA, Morsi ST. Effect of core/veneer thickness ratio and veneer translucency on absolute and relative translucency of CAD-On restorations. Fut Dent J. 2017;3(1):8-14.

22. Wahba MM, El-Etreby SA, Morsi ST. Evaluation of color change in CAD-On restorations using different core/veneer thickness ratios and different veneer translucencies. Fut Dent J. 2018;4(1):90-5.

23. Johnston WM, Ma T, Kienle BH. Translucency parameter of colorants for maxillofacial prostheses. Int J Prosthodont. 1995 JanFeb;8(1):79-86.

24. Chevalier J, Gremillard L, Deville S. Low-temperature degradation of zirconia and implications of biomedical implants. Ann Rev Mater Res. 2007;37:1-32.

25. El-Ghany OS, Sherief AH. Zirconia based ceramics, some clinical and biological aspects: Review. Fut Dent J. 2016;2(2):55-64.

26. Chevalier J. What future for zirconia as a biomaterial? Biomaterials. 2006 Feb;27(4):535-43. Epub 2005 Sep 6. 
27. Wyszecki G, Stiles WS. Color science: concepts and methods,quantitative data and formulae. 2 ed. Toronto: John Willey and Sons Inc; 1982.

28. Deville S, Chevalier J, Dauvergne C, Fantozzi G, Bartolomé JF, Moya JS. Microstructural investigation of the aging behaviour of (3Y-TZP)-Al203 composites. J Am Ceram Soc. 2005;88(5):1273-80.

29. Nakamura T, Usami H, Ohnishi H, Takeuchi M, Nishida H, Sekino T, et al. The effect of adding silica to zirconia to counteract zirconia's tendency to degrade at low temperatures. Dent Mater J. 2011;30(3):330-5. Epub 2011 May 20.

30. Nakamura K. (University of Gothenburg. Sahlgrenska Academy). Mechanical and microstructural properties of monolithic zirconia 2015.

31. Gonuldas F, Yilmaz K, and Ozturk C. The effect of repeated firings on the color change and surface roughness of dental ceramics. J Adv Prosthodont. . 2014;6:309-16.

32. Hamza TA, Alameldin AA, Elkouedi AY, Wee AG. Effect of artificial accelerated aging on surface roughness and color stability of different ceramic restorations. Stomatological Dis Sci. 2017;1:8-13.

33. Douglas RD, Steinhauer TJ, Wee AG. Intraoral determination of the tolerance of dentists for perceptibility and acceptability of shade mismatch. J Prosthet Dent. 2007 Apr;97(4):200-8.

34. Ekren Orhun. The effect of coloring liquid dipping time on the fracture load and color of zirconia ceramics. J Adv Prosthodont. 2017 Feb;9(1):67-73. doi: 10.4047/jap.2017.9.1.67. Epub 2017 Feb 7.
35. Sabet H, Marwa M, Sheif A, Salah T. Effect of different immersion times and sintering temperatures on translucency of monolithic nanocrystalline zirconia. Future Dent J. 2018;4(1):84-9.

36. Luo XP, Zhang L. Effect of veneering techniques on color and translucency of Y-TZP. J Prosthodont. 2010 Aug;19(6):465-70. doi: 10.1111/j.1532-849X.2010.00610.x. Epub 2010 Jun 8.

37. Pecho OE, Ghinea R, Ionescu AM, Cardona Jde L, Paravina RD, Pérez Mdel M. Color and translucency of zirconia ceramics, human dentine and bovine dentine. J Dent. 2012 Dec;40 Suppl 2:e34-40. doi: 10.1016/j. jdent.2012.08.018. Epub 2012 Sep 4.

38. Spink L. (University of Connecticut. Master Degree Thesis) A Comparison of absolute translucency and relative translucency of dental ceramics. 2009.

39. Apetz R, Michel P. Transparent Alumina: A Light-Scattering Model. J Am Ceram Soc. 2003;86(3):480-86.

40. Anselmi-Tamburini U, Woolman JN, Munir ZA. Transparent nanometric cubic and tetragonal zirconia obtained by high- pressure pulsed electric current sintering. Adv Funct Mater.2007;17(16):3267-73.

41. De Jager N, Pallav P, Feilzer A. The influence of design parameters on the FEA determined stress distribution in CAD-CAM produced allceramic dental crowns. Dent Mater. 2005 Mar;21(3):242-51.

42. Teng J, Wang $\mathrm{H}$, Liao Y, Liang X. Evaluation of a conditioning method to improve core-veneer bond strength of zirconia restorations. J Prosthet Dent. 2012 Jun;107(6):380-7. doi: 10.1016/S0022-3913(12)60095-X.

43. Abdelbary 0 , Wahsh $\mathrm{M}$, Salah T. Effect of accelerated aging on translucency of monolithic zirconia. Future Dent J. 2016;2(2):65-9.

\section{Mennatallah Mohie Wahba}

(Corresponding address)

dr menna mohie@yahoo.com

$+\overline{2} 01005 \overline{484253}$

Date submitted: 2018 Jul 17

1st Nabil Abd El-Rahman st. 6th district, Nasr City 